\section{Review of the Volume} "Ipostaze ale simbolului în lumea tradițională" [Hypostases of the Symbol in the Traditional World], Author: Daniel Cojanu, Lumen Publishing House, 2019

\section{Amalia DRĂGULĂNESCU1}

${ }^{1}$ CS III PhD, Romanian Philological Institute "A. Philippide", Romanian Academy - Iasi Branch, amalisa15@outlook.com

\begin{abstract}
Restoring the need of contemporary man for certain signs and symbols, the book " Ipostaze ale simbolului în lumea tradițională" [Hypostases of the symbol in the traditional world], second edition, written by Daniel Cojanu and published by Lumen Publishing House from Iasi, Romania, in 2019, invites to the apparent conciliation between consecrated values and the condition of postmodernity. Structured in two macro-chapters, "Reductionist Hermeneutics" and "Restorative Hermeneutics. Hypostases and Exemplary Functions of the Symbol in the Traditional World ", the volume especially follows "the epistemological and axiological mutations that occurred at the level of fundamental presuppositions and attitudes towards the world" (Cojanu, 2019, p. 9).
\end{abstract}

Keywords: symbol, traditionalism, hermeneutics, Daniel Cojanu.

How to cite: Drăgulănescu, A. (2020). Review of the Volume "Ipostaze ale simbolului în lumea tradițională" [Hypostases of the Symbol in the Traditional World], Author: Daniel Cojanu, Lumen Publishing House, 2019. Journal of Mediation \& Social Welfare, 2(1), 69-75. https://doi.org/10.18662/jmsw/2.1/13 
Mefient față de reducționismul teoriilor moderne despre simbol și evitând narcisismul metodologic, autorul încearcă să recupereze virtuțile hermeneuticii savante ori ale unei interpretări cel puțin neviciate de atingerea simulacrelor actuale. In acest sens, profesorul Daniel Cojanu atrage atenția asupra operației paradoxale de aprop(r)iere de către om a transcendenței, paralelă cu tendința de re-umanizare în plan socio-cultural din zilele noastre. De altfel, teza principală a lucrării se fundamentează pe următoarele considerații: „Simbolul e expresia exemplară, eminentă a unității în diversitate, a unei armonii dinamice şi creatoare. Acesta este paradoxul unităţii în dualitate pe care îl creează dubla natură (şi identitate) a oricărui simbol care este el însuşi şi totodată altceva. Teoriile moderne, sprijinindu-se pe presupozițiile omului modern, reduc unitatea în diversitate a structurii simbolului la omogenitate (...)" (Cojanu, 2019, p. 14). Polemizând, în principiu, cu studiile psihanalitice și cu teoriile structuraliste, exegetul îşsi exprimă unele rezerve față de acestea, pe de o parte, iar pe de altă parte, restituie simbolurilor dimensiunea lor metafizică, dar și întreita lor funcție: cognitivă, expresivă și operativă. Pe mai multe pagini se desfășoară repere importante pentru definirea gândirii de tip simbolic, încă din Antichitate și până spre trecutul recent. Totodată, scriitorul pledează pentru non-arbitrarul simbolisticii, în genere, pentru coeziunea dintre realitatea simbolică și simbolurile propriu-zise, dar și pentru universalitatea acestora. „Echivocul semantic al simbolului tradițional se întemeia pe diferența ontologică. Interpretarea modernă, depinzând de alt set de presupoziții, transformă echivocul semantic în echivoc semiotic, reduce simbolul la o specie de semn, un semn ambiguu, nedeterminat, în care referința glisează nedefinit" (Cojanu, 2019, p. 22), mai adaugă, într-un context mai larg, D. Cojanu. Privite ca instrumente de mediere, în mai multe sensuri, semnele și simbolurile reclamă revenirea la abordarea de formulă organicistă, tradițională, holistică. Pe bună dreptate, se remarcă în cuprinsul volumului faptul de necontestat că ,În plus, semnificația simbolică (transcendentă) e inepuizabilă, cifrată, enigmatică. Indecidabilitatea, echivocul semnificaţiei simbolice se datorează şi faptului că simbolul este un fenomen hibrid, că sensul literal şi cel metafizic sunt ireductibile; simbolul e o aceeaşi monedă, dar cu două fețe; implică revelare şi ocultare" (Cojanu, 2019, p. 28).

Subliniind un anumit raport de semnificare, autorul acestor studii culturale identifică specificitatea simbolului și, mai ales, a cunoașterii simbolice în comparație cu aceea rațională. Atunci când apelează la considerațiile lui C. G. Jung, G. Durand, E. Cassirer or Henri Corbin, cercetătorul observă cu minuțiozitate deosebirile și asemănările dintre semn, 
alegorie și simbol. Îndreptându-se treptat către o bermenentică a imaginii artistice, observă în mod pertinent că „Semnificantul iconic, forma de expresie inevitabilă a artelor plastice, are unele trăsături care îl apropie de simbolul arhetipal. El nu poate fi demontat analitic în unităţi discrete fără a fi denaturat, ci se remarcă printr-o integritate şi o organicitate a expresiei ca şi printr-o transmitere simultană, nesecvențială a semnificației” (Cojanu, 2019, p. 42). În calitate de animal simbolic, omul, ca și artistul, tentează deci să circumscrie spiritualul, simbolurile și exprimarea propriei ființe. Revenind la orientările anterioare, D. Cojanu insistă la modul pozitiv asupra iconologiei lui E. Panofsky, asupra arhetipurilor regăsite în analizele jungiene, asupra structurilor imaginarului durandian, dar și asupra conceptului de numinos al fenomenologului R. Otto. Mai departe, singularizează expresia de „suflet al lumii" pe care o lansase psihologul american James Hillman și valorizează amplele considerații ale lui $\mathrm{G}$. Bachelard despre însemnătatea imaginarului și a elementelor primordiale ca „hormoni ai imaginației”. Cu toate acestea, este relevată insuficiența acestor teorii, prin următoarea completare decisivă: „Am ales ca premisă metodologică analiza corelată a reprezentărilor simbolice neconvenționale şi a culturilor care le favorizează existenţa. Pentru mai multă claritate, voi examina statutul şi dimensiunile simbolului arhetipal în cadrul culturilor tradiționale pornind de la manifestările sale concrete realizări teoretice, opere de artă sau viziuni metafizice. Intrucât este evident că nu se pot inventaria şi analiza toate producțiile spirituale în care gândirea simbolică deține un rol decisiv, mă vor interesa doar acelea care scot în evidenţă caracteristicile definitorii ale simbolului arhetipal. Criteriul de selectare a creațiilor culturale semnificative va fi derivat din principiul metodologic asumat - ele sunt creații reprezentative pentru o anume forma mentis, cea din care se împărtăşesc culturile tradiţionale" (Cojanu, 2019, p. 67). De altminteri, minoratul unor forme și manifestări tradiționale, precum alchimia, magia ori astrologia, este supus unei detaliate analize de către autor. Dacă în lumea premodernă, orice act spiritual semnifica o tentativă de comunicare cu sferele superioare, în sensul larg al termenului, în zilele noastre se constată o paradoxală coborâre în aceste sfere, sub forma reînvierii superstițiilor, a consultării horoscopului zilnic, ori a revigorării practicilor yoga. Așadar, simbolurile dau de gândit în continuare, după cum sună titlul unui studiu semnat de Paul Ricoeur în 1969, și semnalat de autor.

Tocmai de aceea, în capitolul al doilea, consistent și bine întemeiat, se caută o soluție la problematica anterioară, sub forma unei hermeneutici restaurative, cu alte cuvinte o analiză mai mult pe verticală a conținuturilor simbolice, căci „Dezvrăjirea lumii este coextensivă năruirii acestei ordini, 
destrămării marelui lanț al ființei, ce pune în conexiune divinitatea şi ultimul fir de iarbă şi oferă un ambient protector şi furnizor de semnificație pentru om şi proiectele sale de viață" (Cojanu, 2019, p. 88). Această perspectivă este întrucâtva legitimată de reîntoarcerea actuală, măcar în parte, la rădăcinile metafizicii. Chiar dacă materialismul modern pare să fi acaparat aproape toate domeniile, profesorul târgoviștean deslușește lumina de la capătul tunelului postmodern... În mod surprinzător, tradiţia considerată învechită, chiar depășită, asigură continuitatea temporală și coeziunea relațiilor sociale, până la un punct. „Gândirea simbolică şi intuiția intelectuală au nevoie de presupoziția realității obiectelor inteligibile transcendente şi asta este o presupoziție culturală” (Cojanu, 2019, p. 101), mai completează autorul, întrun context mai larg. Deși, parafrazăm, atitudinea tipică omului modern este să nu accepte realitatea a nimic transcendent, acesta admite totuși, mai nou, că există o fantă arhetipală prin care este posibil să se reverse unele elemente ale imaginației simbolice. Pe câteva pagini distincte, eseistul culturii reconsideră liniile de forță ale discursului eliadesc, despre valoarea ancestrală a simbolurilor, despre procesul de inițiere în mai multe sensuri și despre importanța hierofaniilor.

Dincolo de tiparele universale ale simbolurilor, D. Cojanu mai determină și o anumită stratificare simbolică, în sensul adăugirii diacronice a unor valențe noi, așa cum se întâmplă, de exemplu, în relaționarea complexă dintre simbolistica păgână și aceea creștină. Într-o ordine relativă de idei, puterea miturilor provine și dintr-o suprapunere sincronică a fragmentelor simbolice dintr-un areal, de obicei, mai extins. Mergând din aproape în aproape, sunt desfăşurate relațiile dintre centru și periferie, dintre timpul și spațiul calitativ, se face referire la simbolismul numeric, la problematica cercului, la aspectele rotației (roata) ș. a. Mai reține, printre altele, și vădita aversiune structurală a omului arbaic faţă de timpul profan (Cojanu, 2019, p. 124). In chip de concluzie parțială, exegetul consideră că „Sistemele de simboluri prin care omul arhaic îşi defineşte locul în sânul totalității existenței îndeplinesc o funcție orientativă şi axiologică. Structura simbolului arhetipal trimite nemijlocit la o viziune cristalizată despre structura realităţii. Juxtapunerea misterioasă, organică dintre sensibil şi suprasensibil constituie un prim indiciu al unei ontologii scalare, stratificate. Stratificarea nivelurilor realităţii se exprimă spațial ca neomogenitate, ca distincție între un spațiu sacru, centrat şi un spaţiu profan amorf aşa cum se reflectă în conştiinţa omului religios" (Cojanu, 2019, p. 125). Ulterior, declinul cosmologiei simbolice este surprins pornind, în special, de la termenii nominalismului, aniconismului și cartezianismului. De cealaltă parte, a cosmologiei tradiționale, balanța înclină 
în favoarea neoplatonismului, augustinismului și tomismului. Autorul trece apoi la descifrarea unor simboluri exemplare, cum ar fi: cercul, pătratul, cubul, casa, muntele, grota, arborele, crucea, omul, pământul, cerul. Din acestea rezultă o serie de constelații simbolice ca, de pildă, cele aflate în linia axa lumii - arborele cosmic - crucea creștină - omul arhetipal. În subcapitolul referitor la caracterul heteronom al artei tradiționale este acceptată ideea puterii de transfigurare a realităţii prin intermediul metaforelor revelatorii, în literatură, al semnificantului iconic de tip plastic, din pictură ș. a. m. d. Se ajunge astfel la arta simbolică și la frumosul transcendent. $O$ piatră de încercare pentru mentalitatea tradițională a însemnat, de aceea, problema reprezentării divinului în cultura occidentală începând de la Xenofan, Anaximandru, Parmenide, Heraclit, Empedocle, Anaxagora, ba chiar și Platon, care incriminează artele pentru incapacitatea lor de a reprezenta ideile transcendente (Cojanu, 2019, p. 166). Abia odată cu Filon alexandrinul se „sintetizează gândirea elenistică şi revelaţia biblică, atunci când analizează teomorfismul omului, încercând să mențină nealterată transcendența lui Dumnezeu. Omul este într-adevăr imaginea lui Dumnezeu, dar numai prin mijlocirea Logosului, intermediar ipostatic de prim rang (...)" (Cojanu, 2019, pp. 171-172). Etalând consideraţiile lui Iamblicos, Macrobius ori Dionisie Pseudo-Areopagitul, exegetul relatează lupta iconodulilor cu iconoclaștii în principal din secolul al VIII-lea d. Hr. Cât privește caracterul simbolic al artei sacre, aceasta este adeseori impregnată de valori spirituale puternice. Mai târziu, scriitorul reușește cu pricepere să accentueze ideea că monoteismul iudaic și cel musulman nu sunt favorabile reprezentărilor în genere, având drept scop suprem prevenirea idolatriei. Într-o ordine similară de idei, se preocupă de caracteristicile islamismului șiit persan ori de falsul politeism hindus, în fapt un monoteism deghizat. Apoi, în subcapitolul intitulat Arbitectură și iconografie creștină, acceptă preluarea unor elemente figurative și naturaliste din artele greco-romane. Atunci când evocă analogia dintre planul unei biserici creștine și trupul răstignit al lui Hristos, autorul observă cu finețe: „Logosul universal (Hristos) descinde sacrificial în circumstanțele determinate ale unei existențe umane particulare (Iisus), restituind omului vocația de ființă universală, arhetipul său teomorf, condiție indispensabilă pentru transgresiunea limitărilor, privațiunilor şi a morții ce caracterizează existența profană” (Cojanu, 2019, p. 185). Totodată, dedică o secțiune aparte unor meșteșuguri din vechime și practici artizanale specifice: tehnica vitraliilor, metalurgia, orfevrăria, tehnica emailurilor, a preparării culorilor şi tincturilor ș. a. Este interesant de observat că, fiind o religie a întrupării, creștinismul nu rejectează corporalitatea, ci o asimilează în mod creator. Mai 
departe, geniul sincretic al tradiției creștine s-a propagat în 'artele' considerate la început minore, adică aritmetica, geometria, muzica şi astronomia.

Deosebit de importantă se dovedește relația armonioasă icoană canon - prototip metafizic, bine articulată în cuprinsul lucrării științifice. Întorcându-se la democratizarea experienței sacrului, care are loc cu precădere în zilele noastre, se remarcă preferința modernului pentru concret, corporal, contingent în multe dintre domeniile artistice. În celălalt plan, religios, distorsionarea voită a unor reprezentări din icoane ori din frescele bisericești aparține de ceea ce Pavel Florensky (1997) numea la modul inspirat perspectivă inversă. Hermeneutul Dan Cojanu consacră ulterior o parte semnificativă iconoclasmului musulman, explicând radicalismul acestuia printr-un fel de apofatism vis-à-vis de suprimarea expresiei vizuale. Se aduce un adevărat elogiu arhitecturii musulmane, care deține ceva carnal și inefabil deopotrivă: „Arcadele curții din Alhambra, de exemplu, dar şi al altor moschei magrebine se odihnesc într-un calm perfect şi par țesute din vibraţii luminoase. Ele sunt ca lumina cristalizată; pare că materia lor primă nu mai e piatra, ci lumina divină, inteligența creatoare care rezidă misterios în toate lucrurile" (p. 201). În alt plan, diferențele între scrierea aproape monolitică ebraică și arabescurile scrierii islamice țin de mentalitățile structural deosebite între evrei și arabi, inclusiv în conceperea divinităţii. În continuarea analizei stilistice, se situează sanctuarele hinduse care exprimă un soi de multiplicitate, chiar în configurația altarului vedic, ilustrând o dublă operație simbolică (pătrat în cerc și cerc în pătrat), precum și în imaginile uniunii sexuale. Tot aici, autorul mai apreciază fascinanta imagine a omului divin tronând pe lotus, cu alte cuvinte imaginea lui Buddha Sakhyamuni, ca suport de principală meditație pentru lumea asiatică. Iar mai departe, și la propriu, și la figurat, în arta extrem orientală, pictura și, mai ales caligrafia, ca artă de apogeu, indică subtilităţile sufletului chinez sau japonez care tinde a se contopi cu esențele superioare, ajungând la starea de žen.

În concluzie, în acest amplu eseu de filosofie a culturii, autorul cărții subliniază, încă o dată, funcția de mediere a simbolului între vizibil și invizibil, după cum singur precizează. Această funcție este extensibilă și, în mod surprinzător, în plan social, ,atunci când este vorba de agregarea vieții în comun, de funcționarea anumitor instituții, norme şi tradiţii ale societăţilor pre-moderne" (p. 235). Tocmai de aceea adoptă, în definitiv, modelul holist, în tratarea aspectelor legate de simbol, coę̧iunea simbolică şi agregarea comunitară organică devenind două comandamente, în sensul larg al cuvântului, ale societăţii tradiţionale. În cele din urmă, lucrarea se edifică și ca o pledoarie pentru imaginația noetică şi redescoperirea valorilor intrinseci, după spusele 
autorului, prin raportarea analogică la lume, printr-o viziune mai degrabă contemplativă asupra lumii, și prin transfigurarea simbolică a realității, aproape alchimică. Pe bună dreptate, în cuprinsul volumului, uniformitatea, omogenitatea, emanciparea și autonomia, ca însușiri tipice modernității, sunt abandonate în favoarea discursului dictat de valorile arhetipale, cardinale, absolute.

\section{Bibiliografie}

Ricoeur, P. (1969). Le conflit des interpretations. Essais d'hermeneutique [The conflict of interpretations. Essays in hermeneutics]. Seuil.

Florensky, P. (1997). Perspectiva inversă şi alte scrieri [The reverse perspective and other writings], Humanitas.

Cojanu, D. (2019). Ipostaze ale simbolului in lumea tradițională [Hypostases of the symbol in the traditional world]. Lumen. 